OPEN ACCESS

Edited by:

Dinh Duc Nguyen,

Kyonggi University, South Korea

Reviewed by:

Baskar Gurunathan,

St. Joseph's College of Engineering,

Caoxing Huang,

Nanjing Forestry University, China

*Correspondence:

Sabeela Beevi Ummalyma sabeela.25@gmail.com

Specialty section:

This article was submitted to

Bioenergy and Biofuels,

a section of the journal

Frontiers in Energy Research

Received: 13 August 2020

Accepted: 02 November 2020

Published: 08 April 2021

Citation:

Ummalyma SB, Sahoo D,

Pudiyamadam A, Adarsh VP,

Sukumaran RK, Bhaskar $T$ and Parida A (2021) Sono-Assisted Alkali

and Dilute Acid Pretreatment of

Phragmites karka (Tall Reed Grass) to Enhance Enzymatic Digestibility for

Bioethanol Conversion.

Front. Energy Res. 8:594452.

doi: 10.3389/fenrg.2020.594452

\section{Sono-Assisted Alkali and Dilute Acid Pretreatment of Phragmites karka (Tall Reed Grass) to Enhance Enzymatic Digestibility for Bioethanol Conversion}

\author{
Sabeela Beevi Ummalyma ${ }^{1 \star}$, Dinabandhu Sahoo ${ }^{2}$, Anoop Pudiyamadam ${ }^{3}$, \\ Velayudhanpillai Prasannakumari Adarsh ${ }^{3}$, Rajeev K. Sukumaran ${ }^{3}$, Thallada Bhaskar ${ }^{4,5}$ and \\ Ajay Parida ${ }^{6}$
}

\begin{abstract}
${ }^{1}$ Institute of Bioresources and Sustainable Development (IBSD), A National Institute under Department of Biotechnology, Govt of India Takyelpat, Imphal, India, ${ }^{2}$ Department of Botany, University of Delhi, Delhi, India, ${ }^{3}$ Microbial processes and Technology Division, Centre for Biofuels National Institute for Interdisciplinary Science and Technology-CSIR, Trivandrum, India, ${ }^{4}$ ThermoCatalytic Processes Area (TPA), Material Resource Efficiency Division, Indian Institute of Petroleum-CSIR, Dehradun, India, ${ }^{5}$ Academy of Scientific and Innovative Research (AcSIR), Ghaziabad, India, ${ }^{6}$ Institute of Life Sciences, NALCO Square, Bhubaneswar, Odisha, India
\end{abstract}

Phragmites is the tallest energy crop found as an invasive species worldwide and considered as waste biomass. The present study evaluated the potential of the aquatic biomass Phragmites karka grown from two different lakes as feedstock for biofuel production. A comparative study of biomass was conducted from Chilika Lake and Loktak Lake, India. The methodology involves dilute acid, sono-assisted alkali pretreatment, and hydrolyzed biomass with commercial cellulase. SEM, XRD, and FTIR analysis were performed for the biomass physicochemical studies and confirmed that alterations occurred in the biomass structure, assisting the hydrolysis process. The enzymatic hydrolysis result showed that the highest of reducing sugar yield of $79 \%$ was obtained from biomass loading of $10 \%$ and $1 \% \mathrm{w} / \mathrm{v}$ alkali with a sonication frequency of $20 \mathrm{kHz}$ for $25 \mathrm{~min}$. Acid pretreatment released maximal reducing sugar yield of $73 \%$ attained from biomass loading of $20 \%$ and $0.5 \% \mathrm{w} / \mathrm{v}$ acid. Composition analysis of biomass showed that cellulose content increased from $36 \%$ to $46 \%$. Sono-assisted alkali pretreatment solubilized $40 \%$ of lignin content compared to untreated biomass. Final ethanol recovery from the biomass is $78 \%$ fermentation efficiency from glucose. The data indicate that exploiting tall reed grass as a bioenergy raw material can be a viable approach for sustainable utilization of invasive grass/waste biomass for biorefineries, which helps control invasive weeds and management of waste.

Keywords: Phragmites, sonication, pretreatment, Chilika Lake, Loktak lake 


\section{INTRODUCTION}

Worldwide energy demand is increasing, and its soaring price leads to looking for an alternative sustainable solution for fossil fuels. Biomass from lignocelluloses is feasible alternatives to fossil fuels for solving energy demands for the future. The lignocelluloses biomass is a potent source of sugars, and availability with energy vs. food competition status made it an inexpensive and readily available raw material for biofuels (Sivagurunathan et al., 2017; Baruah et al., 2018). Lignocellulosic biomass predominantly comprises cellulose, hemicellulose, and lignin joined together in a compact structure. The tight binding of these molecules will give recalcitrance to the biomass, which will affect the enzymatic efficiency during hydrolysis (Sun et al., 2016; Sivagurunathan et al., 2017; Sahoo et al., 2018). The current cost of ethanol from cellulosic biomass is comparatively higher due to the cost of enzyme and low hydrolysis efficiency (Sukumaran et al., 2010; Zhu et al., 2015). Therefore, different pretreatment strategies are employed to reduce biomass recalcitrance by breaking the linkages between cellulose, hemicelluloses, and lignin complex. However, different pretreatment approaches such as physical, chemical (either acids or alkali), and combined physiochemical treatment and biological pretreatments were evaluated to meet the target as mentioned earlier (Ravindran and Jaiswal, 2016; Liu and Bao, 2019; Hassan et al., 2020). In addition to this, structural alterations of lignin and cellulose are required to increase cellulase enzyme accessibility to cellulose for releasing sugars. Pretreatment steps can also aid in degrading/remove lignin and hemicelluloses, which is also a contributing factor for improving enzyme efficiency (Huang et al., 2019). Hence, the pretreatment steps disorganize the cellulosic fiber and cellulose polymers exposed to the surface, which assists efficient enzyme action.

Low-cost pretreatment methods are highly preferred in lignocellulosic biorefineries for better hydrolysis efficiency for biofuel and other platform chemicals. Characteristics of suitable pretreated biomass for enzymatic hydrolysis are the increase of pore size for enzyme infiltration and less lignin with crystallinity, which helps minimize the physical barriers of biomass and avoids association of enzyme with lignin (Kim et al., 2015). Commonly preferred pretreatment process for biomass is alkali, steam explosion, and acids (Soares et al., 2016; Sindhu et al., 2017; Sahoo et al., 2018; Huang et al., 2019). Alkaline pretreatments break the ester linkages between hemicelluloses and lignin, which further helps for the solubilization of lignin and hemicelluloses. This step helps to expose cellulose to the surface (Balat et al., 2008; Bensah et al., 2019). While dilute acid pretreatment disintegrates the hemicelluloses efficiently, this process generates some toxic compounds (hydroxymethyl furfural and furfural) produced due to the degradation of C5 and C6 sugars, which affect the fermentation process (Zhong et al., 2017). Hence, chemical treatment of either acids or alkali is not efficient and time-consuming; therefore, combined physicochemical pretreatment of alkali with ultrasound is preferred due to better efficiency (Zhong et al., 2017; Hassan et al., 2020). The energy from sonication gives unique physicochemical surroundings for processing biomass (Ensminger and Bond, 2011). It could act on the lignin-hemicellulose barriers and break the linkages. The process assists chemicals used for pretreatment to reach the cellulosic fibers and increase the cellulose accessibility by enzymes (Koutsianitis et al., 2015). The sonication process is a potential alternative pretreatment for lignocellulosic biomass for enhancing sugars for biofuels (Bussemaker and Zhang, 2013; Hassan et al., 2020; Ong and Wu, 2020).

Reed grasses are perennial grass, one of the promising energy crops due to its fast growth, widely spread in wetland, and terrestrial habitat. These grasses are resistant to harsh environmental conditions such as prolonged drought, flood, contaminated soil, and degraded lands. Due to its vigorous growth and difficult to control, some parts of the world reed are considered an invasive weed. This grass is recently given more attention as a promising renewable energy source due to its fast growth and biomass production (Cavalaglio et al., 2016; Pandey and Maiti, 2020; Zhao et al., 2020).

The natural freshwater source in Northeastern India is Loktak Lake, and the beauty of the lake is the presence of floating wetlands called phumdis, found only in Manipur. In contrast, Chilika Lake is a brackish water coastal wetland of Odisha State, India. Phumdis of Loktak and Chilika Lake found abundant availability of aquatic invasive tall reed grass (Phragmites karka). Local people removed this biomass due to uncontrollable growth in the lake and dumping on the shore of the lake. This grass invades and outcompetes with indigenous native species of the lake. Hence, overgrowth of these tall reed grasses in these lakes loses its natural and economic values due to disruption in biodiversity and ecology. One possible option for controlling tall reed grasses is the commercial exploitation of these grasses for biofuels and other value-added products, which will help waste management (Zhao et al., 2020). The present study illustrates the comparative evaluation of tall reed grass from Loktak Lake and Chilika Lake as feedstock for bioethanol conversion. Dilute acid and sonication-assisted alkali pretreatments were conducted. The enzymatic hydrolysis was done to assess the digestibility of pretreated biomass. Pretreated biomasses are characterized by crystallinity and structural alteration analysis with the help of SEM, FTIR, and XRD. Fermentation studies for ethanol conversion of hydrolysate obtained from the biomass were performed using wild yeast cells, and sugar consumption and ethanol production were analyzed from the samples collected.

\section{EXPERIMENTAL MATERIALS AND METHODS}

\section{Biomass}

Biomass of tall reed grass was collected from Loktak Lake and was dried in an oven at $50^{\circ} \mathrm{C}$ for $48 \mathrm{~h}$. The size reduction of biomass was carried out to get a particle size of $1 \mathrm{~mm}$. Chilika Lake biomass is provided by the Institute of Life Sciences, Bhubaneswar, Odisha. Milled biomass was homogenized and 
stored in the laboratory. The moisture content of powdered biomass was $9.8 \%$.

\section{Pretreatments}

The pretreatment experiment of biomass was carried out in a $250 \mathrm{ml}$ beaker containing biomass loading of $10 \%$ and $1 \%(\mathrm{w} / \mathrm{v})$ of alkali $(\mathrm{NaOH})$. The reaction mixtures were used for sonication using a sonicator (Sonics Vibra cells, Kolkata) with a prob tip diameter of $1.0 \mathrm{~cm}$ and frequency of $20 \mathrm{kHz}$ with an output power of $650 \mathrm{~W}$ for $15-40 \mathrm{~min}$. Acid pretreatment of biomass was conducted with 10 and $20 \%$ biomass loading with $0.5,1.0$, and $2 \% \mathrm{w} / \mathrm{v}$ of $\mathrm{H}_{2} \mathrm{SO}_{4}$. The biomass is washed using tap water until neutral $\mathrm{pH}$. The separated solid fraction was dried and stored for further use.

\section{Biomass Chemical Composition}

The chemical composition of tall reed grass of pretreated and untreated samples was performed to know the component such as cellulose, hemicellulose, and lignin as per NREL analytical protocol (Sluiter et al., 2011). Sugars obtained after the hydrolysis process were quantified and analyzed with HPLC having an RI detector (Shimadzu Prominence UFLC) and Rezex RPM monosaccharide column (Phenomenex). Deionized water (mobile phase) was used with a flow rate of $0.8 \mathrm{ml} / \mathrm{min}$ and $80^{\circ} \mathrm{C}$ temperature maintained for the oven.

\section{SEM Analysis}

Electron microscopy is conducted to evaluate any changes that occurred with the surface of pretreated biomass. The analysis of the samples was performed with an electron microscope of Zeiss Evo 17 SE, Germany.

\section{FTIR Analysis}

FITIR analysis was performed to understand the structural variations in functional groups of pretreated biomass using a Shimadzu IRT racer-100 spectrometer (Japan). Approximately, $2 \mathrm{mg}$ of biomass samples was mixed with $100 \mathrm{mg}$ of $\mathrm{KBr}$. A pellet of $12 \mathrm{~mm}$ was prepared by pressing mixture in a standard device using 600 psi. The spectrum obtained for potassium bromides was subtracted from sample spectra. FTIR gives information on the structure and bonding nature of biomass. The spectra were attained from 20 scans of average with a resolution of $0.25 \mathrm{~cm}^{-1}$ with in the array of $4000-600 \mathrm{~cm}^{-1}$.

\section{Crystallinity Analysis}

The biomass crystallinity analyses of pretreated and untreated samples were performed with an X-ray diffractogram (PANalytical, the Netherlands). Pretreated and untreated dried samples are powdered and pressed into a tablet. X-ray diffractograms (XRDs) are recorded from $5^{\circ}$ to $40^{\circ}$ with a

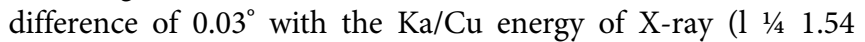
$\mathrm{A}^{\circ}$ ) produced with a voltage of $40 \mathrm{kV}$ and current of $30 \mathrm{~mA}$. The calculation of crystallinity was performed based on the equation as follows (Segal et al., 1959):

$\operatorname{CrI}(\%)=\left[\mathrm{I}_{002}-\mathrm{I}_{\mathrm{AM} / \mathrm{I}_{002}}\right]_{\times} 100$,

where $\mathrm{I}_{\mathrm{AM}}$ represents the peaks for amorphous cellulose and $\mathrm{I}_{002}$ represents the peak of the crystalline part.
TABLE 1 | Composition of Phragmites collected from Loktak Lake and Chilika Lake.

\begin{tabular}{lcc} 
Composition (\%) & P.karka Loktak & P.karka Chilika \\
\hline Cellulose & $36.7 \pm 3.3$ & $34.7 \pm 1.6$ \\
Hemicellulose & $20.3 \pm 2.5$ & $19.7 \pm 2.5$ \\
Lignin & $24.6 \pm 0.4$ & $27.9 \pm 1.2$ \\
Ash & $4.4 \pm 1.2$ & $5.5 \pm 0.6$ \\
Extractives & $13.6 \pm 0.6$ & $12 \pm 0.7$ \\
\hline
\end{tabular}

\section{Saccharification}

The biomass saccharification of pretreated and untreated tall reed samples was conducted in a150 ml flask. The hydrolysis was carried out with 20FPU/g biomass of acid cellulase (Zytex Pvt. Ltd, Mumbai, India). The activity of different enzymes available in this enzyme cocktail was reported previously by Puthiyamadam et al. (2019). Biomass loading of $2 \%(w / w)$ along with $200 \mu \mathrm{L}$ of $10 \mathrm{X}$ antibiotic solution (Himedia), tween 80 as a surfactant $(0.1 \%)$, and $0.1 \mathrm{M}$ citrate buffer was used for the final volume up to $20 \mathrm{ml}$. The reaction mixture was kept in a water bath $\left(50^{\circ} \mathrm{C}\right)$ with $100 \mathrm{rpm}$ for $48 \mathrm{~h}$. Samples are collected for sugar estimation from $0 \mathrm{~h}$ to $48 \mathrm{~h}$, centrifuged, and the supernatant was used for evaluation of glucose by DNS assay, according to Miller (1959).The efficiency of enzymatic hydrolysis was calculated by the equation reported by Huang et al. (2019).

\section{Fermentation of Hydrolysate}

Fermentation was carried out from the concentrated hydrolysate of sono-alkali pretreated biomass. The experiment was performed in a $20 \mathrm{ml}$ glass vial with $10 \mathrm{ml}$ hydrolysate as a working volume. The vial was inoculated with a $4 \%$ (wet v/v) $24 \mathrm{~h}$ old culture of wild yeast SFAY2 and incubated under static conditions at $30^{\circ} \mathrm{C} \pm$ 2 for $48 \mathrm{~h}$. Samples were collected and analyzed for sugar depletion and ethanol concentration.

\section{RESULT AND DISCUSSION}

\section{Biomass Composition of Tall Reed Grass}

Biomass component analysis showed that Loktak Lake tall reed grass contains cellulose content $37 \%$, hemicellulose $20 \%$, and lignin $24.6 \%$. While in the case of Chilika Lake, biomass consists of cellulosic material 34.7, hemicelluloses 19.7\%, and lignin $27.9 \%$, respectively. Variation in the composition could be due to the biomasses are from different lakes and climatic conditions, which could affect the biomass composition. Composition analyses of native Phragmites karka collected from two different lakes are shown in Table 1. Composition analysis supports an earlier report on Phragmites (Cavalaglio et al., 2016). Sonication-assisted alkali-pretreated biomass from Loktak Lake showed that cellulosic content increased by $45 \%$. The hemicelluloses content reduced to $13.8 \%$ and lignin solubilization to $40 \%$. While sonication-assisted alkali pretreatment of Chilika Lake biomass showed, cellulosic content increased from $34.7 \%$ to $40 \%$, hemicellulose reduction to $10.8 \%$, and lignin reduced to $30 \%$. The biomass pretreated with 
TABLE 2 | Compositional analysis of pretreated Phragmites from Loktak Lake and Chilika Lake.

\begin{tabular}{|c|c|c|c|c|}
\hline Composition (\%) & P.karka (Loktak) sono-alkali & P.karka (Loktak) acid & P.karka (Chilika) sono-alkali & P.karka (Chilika) acid \\
\hline Cellulose & $45 \pm 5.3$ & $41 \pm 0.8$ & $40 \pm 0.1$ & $39 \pm 0.7$ \\
\hline Hemicellulose & $13.8 \pm 0.8$ & $6.3 \pm 0.7$ & $10.8 \pm 1.9$ & $4 \pm 0.3$ \\
\hline Lignin & $9.8 \pm 0.4$ & $24 \pm 0.4$ & $8.5 \pm 1.2$ & $28 \pm 1.4$ \\
\hline Ash & $6.6 \pm 0.4$ & $3 \pm 0.7$ & $7.9 \pm 0.6$ & $6.5 \pm 0.07$ \\
\hline Extractives & $7.3 \pm 0.7$ & $6.8 \pm 0.8$ & $7 \pm 1$ & $5.8 \pm 0.1$ \\
\hline
\end{tabular}

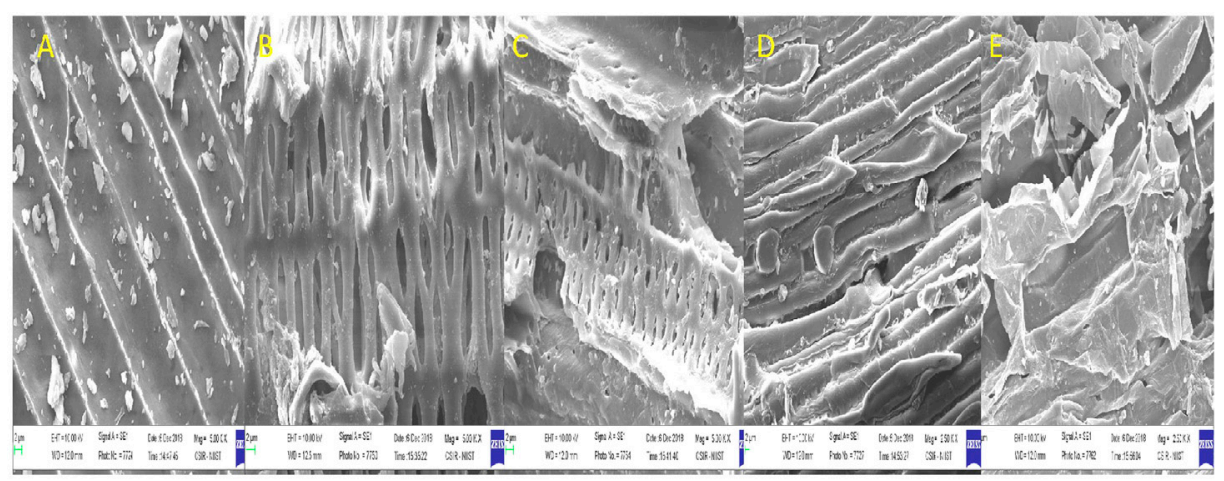

FIGURE 1 | Scanning electron microscopic images of pretreated biomass. Legends: (A) native, (B) sono-alkali Chilika Lake, (C) sono-alkali Loktak Lake, (D) acid Chilika Lake, and (E) acid Loktak Lake.

dilute acids showed cellulose content $41 \%$, hemicellulose $6.3 \%$, and lignin content $24 \%$ obtained from Loktak biomass. Meanwhile, Chilika Lake acid-treated biomass showed a cellulose content of $39 \%$, hemicellulose $4 \%$, and $28 \%$ lignin. The compositional changes of Phragmites karka samples after different pretreatment processes are represented in Table 2. Usually, acid pretreatment of biomass solubilizes the hemicellulose, improving enzymatic digestibility (dos Santos et al., 2018). Sono-alkali pretreatment is an attractive process that selectively acts on the lignin and hemicellulosic portion of biomass and helps for an increase of cellulosic content. Hence, it decreases the lignin and hemicellulose of biomass (Zhu et al., 2015; Hassan et al., 2020). Hemicellulose and lignin contents of biomass inhibit cellulase enzyme action on cellulose. This disintegration can enhance accessible surface and increase pore size for cellulose accessibility and aids in improved efficiency of hydrolysis (Sindhu et al., 2017; Wu et al., 2017). Sonication-assisted alkali treatment is recently reported in the case of feedstocks from brewers spent grain, wheat straw, sugarcane bagasse, grass clipping, and chili postharvest residues (Sindhu et al., 2017; Wang et al., 2017; Zhong et al., 2017; Hassan et al., 2020). Reports are limited in the literature for the exploitation of Phragmites as feedstock for biofuel.

\section{Scanning Electron Microscopy Analysis}

Pretreatment can affect the structure of lignocellulose. SEM analyzes the alterations in the morphological structure of untreated and pretreated biomass. Untreated biomass of tall reed grass has an intact, organized, and smooth surface without any erosion (Figure 1A). Biomass pretreated with dilute acids showed that fibers are ruptured and detached, which further aid in the exposure of active site in the biomass for hydrolyzing enzymes (cellulase) (Figures 1D,E). In the case of ultrasound-assisted alkali-pretreated biomass is rougher and fibers are entirely disorganized, cellulosic fiber bundles are exposed to the surface, and swelling nature is observed (Figures 1B,C). This further helps expose more cellulose fiber that assists in an increase in cellulase accessibility for the release of more fermentable sugars. Identical observations are also reported by Wang et al. (2017) for grass clipping, brewers spent grains by Hassan et al. (2020) and Ramadoss and Muthukumar (2016) for sugar cane bagasse.

\section{FTIR Analysis}

Enzymatic digestibility of pretreated biomass depends on the alterations of chemical bonds, structure, and quality of the pretreatment process. The biomass functional groups and structural alteration of pretreated biomass were analyzed by FTIR (Figures 2A,B). The absorption peak positions were assigned according to the literature on biomass chemical composition (Chung et al., 2004; Raiskila et al., 2007; Wang et al., 2011; Pandiyan et al., 2014). Lignin-related information was obtained from the FTIR band spectra around $1850-600 \mathrm{~cm}^{-1}$. Higher lignin reduction was observed in sonication-assisted alkali-pretreated Phragmites samples than in acid pretreatment, further supporting changes in 

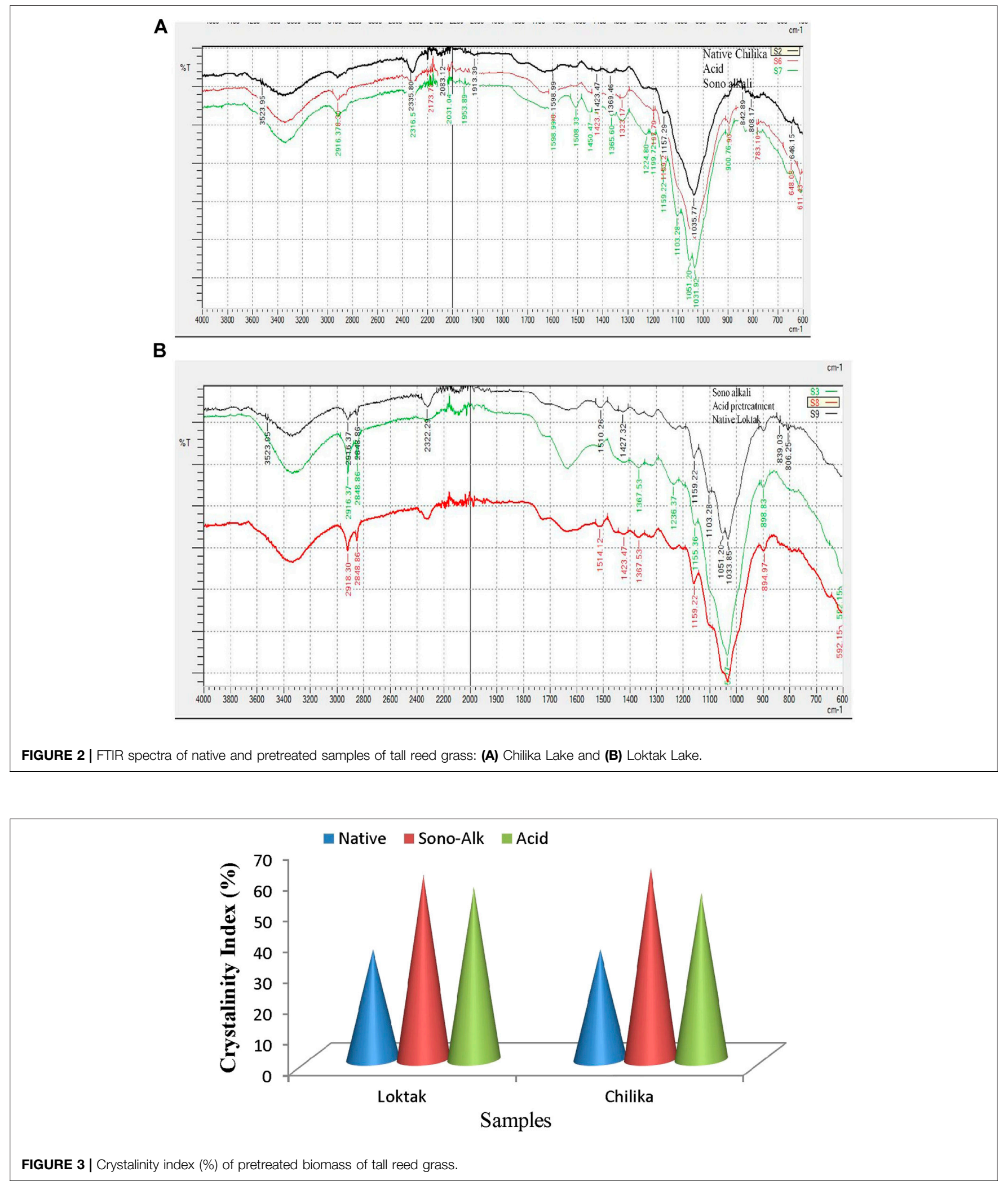

the surface morphology of biomass obtained from SEM data. The intensity band reduction at $897 \mathrm{~cm}^{-1}$ provides cellulose details, especially $\beta-D$ linkages of glycosidic bonds and the absorption spectra from 1,635 to $1,640 \mathrm{~cm}^{-1}$, representing the vibrations of water bending (Borirlau et al., 2010). The information regarding stretching $\mathrm{C}-\mathrm{O}$ bonds of lignin 


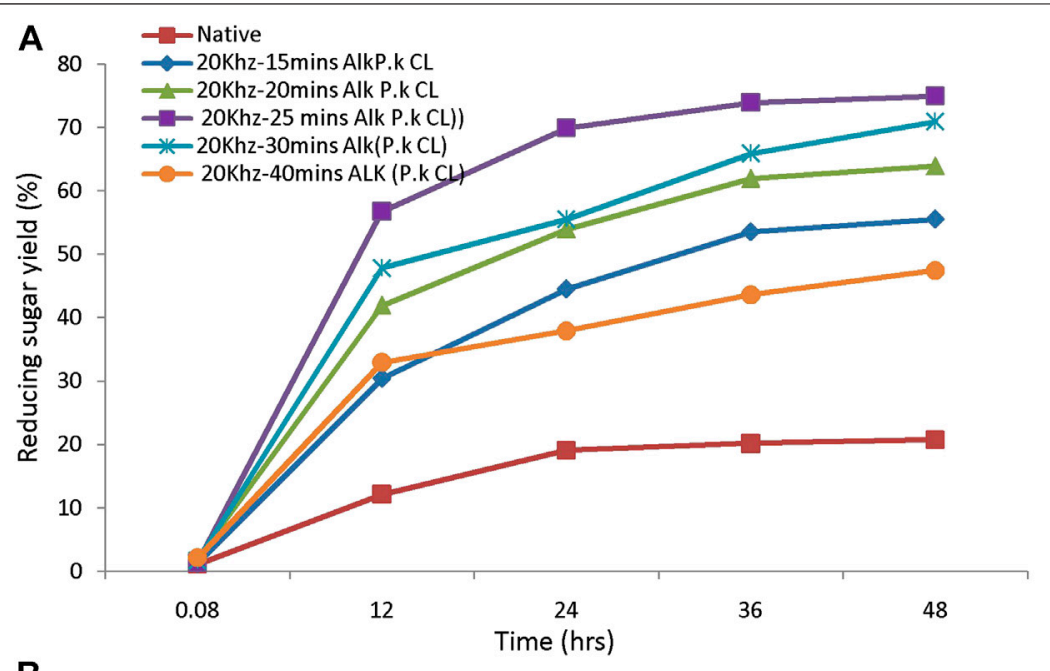

B

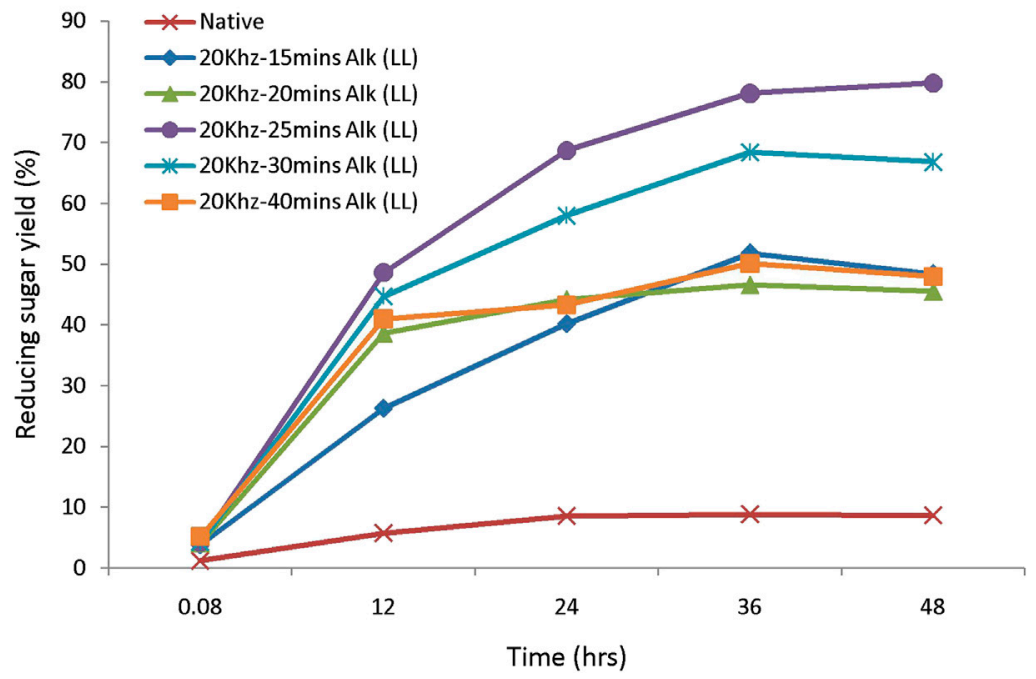

FIGURE 4 | The enzymatic hydrolysis efficiency of sono-assisted alkali-pretreated tall reed biomass: (A) Chilika Lake and (B) Loktak Lake.

guaiacyl group, hemicellulose, or cellulose was obtained from peaks at $1,037 \mathrm{~cm}^{-1}$ (Chung et al., 2004). The $\mathrm{C}=\mathrm{O}$ of ketone groups showed a sharp intensive peak around $2,350 \mathrm{~cm}^{-1}$ (Pandiyan et al., 2014). CH stretching-related information was obtained at $2,800-3,000 \mathrm{~cm}^{-1}$, and $\mathrm{OH}$ stretching of cellulose represented spectra around $3,550-3,100 \mathrm{~cm}^{-1}$ (Chung et al., 2004). The alterations of absorption peaks of pretreated biomass could affect the crystallinity, which is confirmed by XRD.

\section{X-Ray Diffraction Analysis}

Crystallinity index analysis is an important factor used to assess the hydrolytic process of pretreated biomass. The crystallinity of biomass is calculated according to the formula provided by Segal et al. (1959). It found that the crystallinity index of native biomass was $33.5-34.8 \%$. It further increased to $62 \%$ in sono-assisted alkali-treated biomass of Chilika Lake and Loktak Lake (60\%). For the acid-treated biomass, the crystallinity index increased from 54 to $56 \%$ from Chilika Lake and Loktak Lake biomass. CrI signifies the comparative numbers of crystalline cellulose availability in total solids of biomass. The crystallinity index of pretreated biomass of tall reed grass is represented in Figure 3. The removal of amorphous lignin is reflected in enhancing crystallinity in pretreated biomass. Higher crystallinity index in sono-assisted alkali pretreatment could be explained by removing lignin and exposing the biomass cellulosic content compared with acid-pretreated and untreated biomass. Hence, the maximum value in sono-alkali pretreatment confirms that sono-assisted pretreatment is better for biomass processing for ethanol. This observation agreed with an earlier report of an increase in CrI values during sono-assisted pretreatment of rice straw (Wu et al., 2017), grass clipping (Zhong et al., 2017), and cotton stalk (Wang et al., 2016).

\section{Enzymatic Hydrolysis}

The saccharification process of pretreated samples is an essential step in the lignocellulosic biorefinery. The yield of sugars from pretreated feedstock mainly depends on enzymes used for 


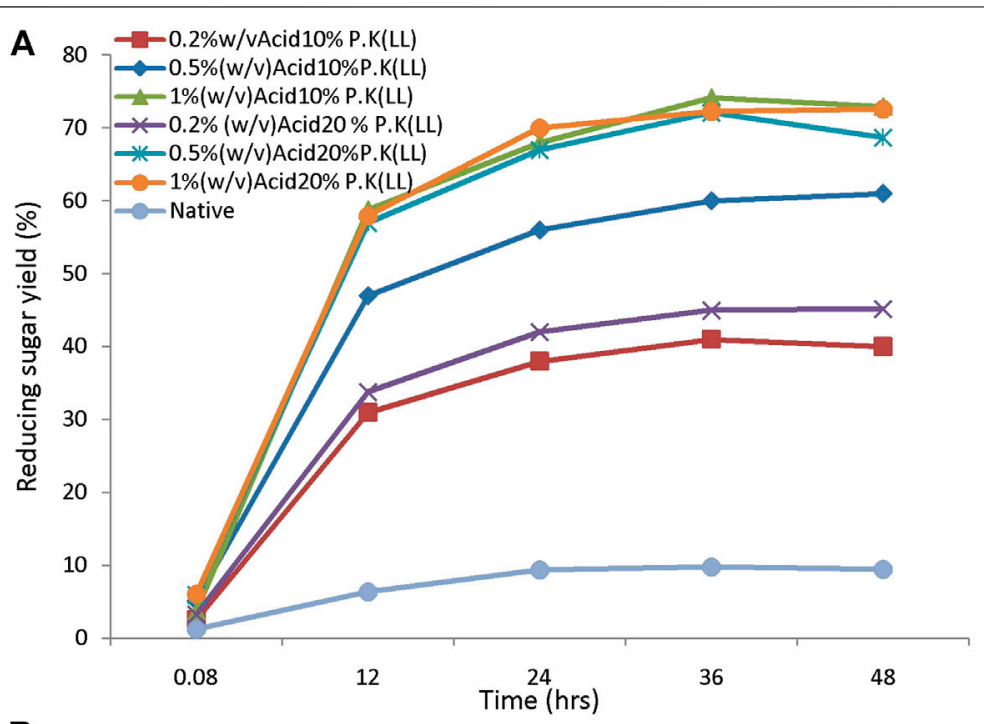

B

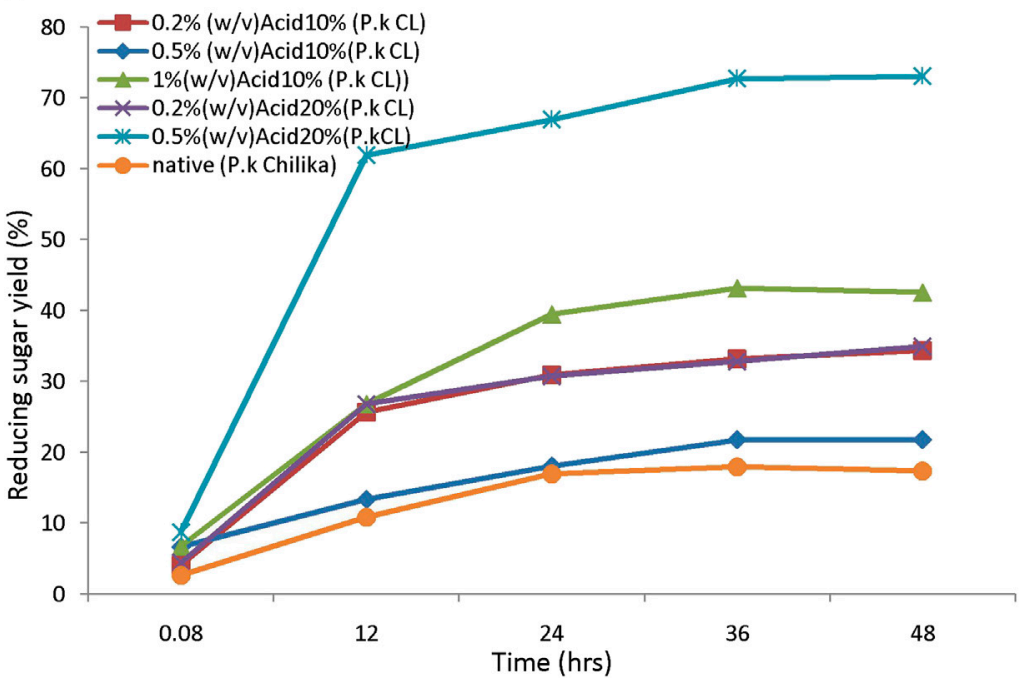

FIGURE 5 | The enzymatic hydrolysis efficiency of acid-pretreated tall reed biomass: (A) Loktak Lake and (B) Chilika Lake.

hydrolysis, active site presence, and the biomass porosity. These characters further depend on the loading of the enzyme and hydrolysis duration, which will affect the bioprocess (Sukumaran et al., 2010). The efficiency of the pretreatment process is further evaluated by monitoring the susceptibility to enzymatic hydrolysis. The pretreated biomass was subjected to hydrolysis by using 20FPU/g of cellulose. Sugar yields were analyzed by the DNS method. Hydrolysis of biomass pretreated with different alkali concentrations ranges from $0.5,1$, and $1.5 \%(\mathrm{w} / \mathrm{v})$ and produces reducing sugar yield from 12,20 , and $15 \%$, respectively. The highest yield of sugar was obtained from biomass pretreated with $1 \%(\mathrm{w} / \mathrm{v})$ of alkali. This concentration was chosen further for the sonicationassisted alkali pretreatment. Hydrolysis of sono-alkali treated biomass with different time intervals showed that reducing sugar yield increased with increasing time. The highest enzymatic digestibility of sono-alkali pretreated biomass with $48-79 \%$ reducing sugar yields was obtained from biomass loading of 10 and $1 \% \mathrm{w} / \mathrm{v}$ alkali with a sonication frequency of $20 \mathrm{kHz}$ for $25 \mathrm{~min}$ from Loktak Lake biomass. For the enzymatic digestibility of Chilika Lake biomass, maximum reducing sugar yield obtained is $75 \%$ from alkali-treated biomass with a sonication frequency of $20 \mathrm{kHz}$ for $25 \mathrm{~min}$ (Figures 4A,B). Results agreed with the earlier report on ultrasound-assisted alkali pretreatment of grass clipping (Wang et al., 2017). Acidpretreated biomass showed that maximal reducing sugar yield of $72-73 \%$ was attained from $10 \%$ to $20 \%$ biomass pretreated with $0.5-1 \%(\mathrm{w} / \mathrm{v})$ dilute acid from Loktak Lake and Chilika Lake biomass, respectively (Figures 5A,B). The differences in the reducing sugar yield from different pretreatment process are due to the ratio of delignification and solubilization of hemicelluloses. An earlier report showed that reduction in enzymatic hydrolysis yield is due to physical barriers of lignin and nonproductive adsorption of enzymes (Huang et al., 2019). Huang et al. also reported that the accessibility of pretreated biomass was enhanced and further improved the digestibility of biomass with enzymes, supporting with the present 
study. Higher reducing sugar yield from pretreated biomass might be due to more pore size, the surface area of cellulosic content, decreased lignin, and hemicellulosic content of biomass (Baruah et al., 2018; Lin et al., 2020). It has been reported that the application of ultrasound during the pretreatment process acts as an auxiliary source of energy for solid-liquid separation of bioprocess technology, mass transfer, and diffusion. This is mainly due to microbubble formation during sonication-assisted pretreatment (Gracia et al., 2011). Velmurugan and Muthukumar (2012) showed that higher reducing sugars from ultrasound-assisted pretreated biomass are due to cavitation formation in aqueous media, which creates high shear forces, pressure, and temperature. Cavitation facilitates the formation of free radicals from water molecules breakdown, which help to break the network of hemicellulose and lignin (Iskalieya et al., 2012).

\section{Fermentation}

Fermentation of hydrolysate from Phragmites biomass is done without further detoxification process with wild yeast. After fermentation, it is shown that ethanol concentration was $3.4 \%$ with a fermentation efficiency of $78.6 \%$, which is calculated based on the theoretical yield of ethanol after $48 \mathrm{~h}$. The less efficiency might be due to inhibitory compounds produced due to the degradation of sugar molecules during the pretreatment process and hydrolysis, affecting microorganism performance during the fermentation process. The results supported with the previous reports from Phragmites australis (Gao et al., 2014). Puthiyamadam et al. (2019) reported that hydrolysate obtained from wet biomass processing of Loktak mixed biomass produced a fermentation efficiency of $95 \%$ with wild yeast. The efficiency of fermentation may be improved with the optimization of different process parameters. The present study indicates that sonicationassisted alkali pretreatment is a better approach for obtaining sugars for biofuel (bioethanol) conversion. Furthermore, the exploitation of P.karka for bioenergy application is a feasible alternative solution for controlling invasive grass and the management of waste biomass.

A sustainable analysis of Phragmites karka biomass as raw material for biofuels and biorefinery products needs to be evaluated in future studies.

\section{CONCLUSION}

The invasive aquatic tall reed grass found in Loktak Lake and Chilika Lake is a promising feedstock for biofuel production

\section{REFERENCES}

Balat, M., Balat, H., and Oz, C. (2008). Progress in bioethnaol processing. Prog. Energy Commust. Sci. 234 (5), 551-573. doi:10.1016/j.pecs.2007.11.001

Baruah, J., Nath, B. K., Sharma, R., Kumar, S., Deka, R. C., Baruah, D. C., et al. (2018). Recent trends in pretreatment of lignocellulosic biomass for value added products. Front. Energy Res. 6, 141. doi:10.3389/fenrg.2018.00141

Bensah, E. C., Kadae, Z., and Mensah, M. Y. (2019). Alkali and glycerol pretreatment of West African biomass for production of sugars and ethanol. Bioresour. Technol. Rep. 6, 123-130. doi:10.1016/j.biteb.2019.02.013 without compromising food crops. Sonication-assisted alkali pretreatment is useful to improve the saccharification process of Phragmites karka. Results showed that ultrasound alkaline pretreatment significantly enhanced the solubilization of lignin and hemicellulose, reflected in cellulose increased crystallinity. Hence, sono-alkaline pretreatment is superior to the acid pretreatment process, and the efficiency of ethanol produced is $78.6 \%$ with the theoretical maximum. However, utilization of tall reed grass as a biorefinery energy crop from these regions can be a solution for addressing control, exploiting tall reed grass for people's socioeconomic benefit and managing waste biomass for industrially important products.

\section{DATA AVAILABILITY STATEMENT}

The raw data supporting the conclusions of this article will be made available by the authors, without undue reservation.

\section{AUTHOR CONTRIBUTIONS}

SU contributed to experiment, data collection, visualization, and writing original manuscript-review and editing. DS was responsible for conceptualization and formal analysis. AP, VA, and RS performed compositional analysis and characterization of biomass. TB carried out physicochemical analysis of the structure of biomass. AP was involved in providing data about Phargmites from Chilika Lake.

\section{FUNDING}

This study was supported by the Institute of Bioresources and Sustainable Development Core Fund.

\section{ACKNOWLEDGMENTS}

SU is thankful to the Director of IBSD for his motivation and support for this work. The authors are grateful to Microbial Processes Technology for their extensive help in FTIR analysis, the Electron Microscopy Section for SEM, and the Chemical Sciences Division of NIIST-CSIR, Trivandrum (MS no. IBSD/ 2020/01/032), for XRD analysis.

Borirlau, R., Teaca, C. A., and Spiridon, I. (2010). Influence of ionic liquids on hydrolysed cellulosic material: FTIR spectroscopy and TG-DTG-DSC analysis. Int. J. Polm. Anal. Charact. 15 (7), 460-469. doi:10.1080/1023666X.2010. 510112

Bussemaker, M. J., and Zhang, D. (2013). Effect of ultrasound on lignocellulosic biomass pretreatment for biorefinery and biofuel application. Ind. Eng. Chem. Res. 52, 3563-3580. doi:10.1021/ie3022785

Cavalaglio, G., Gelosia, M., Ingles, E., Pompilli, E., Antonio, S. D., and Cotana, F. (2016). Response surface methodology of cellulosic ethanol production from Phragmites australis through presaccharification and fermentation. Ind. Crops Prod. 83, 431-437. doi:10.1016/j.indcrop.2015.12.089 
Chung, C., Lee, M., and Choe, E. K. (2004). Characterization of cotton fabric scoring by FTIR ATR spectroscopy. Carbohyd. Polym. 58, 417-420. doi:10. 1016/j.carpol.2004.08.005

dos Santos, L. C., Adarme, O. F. H., Baeta, B. E. L., Gurgel, L. V. A., and de Aquino, S. F. (2018). Production of biogas (methane and hydrogen) from anaerobic digestion of hemicellulosic hydrolysate generated in oxidative pretreatment of coffee husk. Bioresour.Technol. 263, 601-612. doi:10.1016/j.biortech.2018.05.037

Ensminger, D., and Bond, L. J. (2011). Ultrasonic: fundamentals, technologies and applications. CRC Press.

Gao, K., Boinano, S., Marzocchella, A., and Rehmann, L. (2014). Cellulosic butanol productions from alkali pretreated Switch grass (Panicum virgatum) and Phragmites (Phragmites australis). Bioresour. Technol. 174, 176-181. doi:10. 1016/j.biortech.2014.09.152

Gracia, A., Alriols, M. G., Lianno-Ponte, R., and Labidi, J. (2011). Ultrasound assisted fractionization of the lignocellulosic material. Bioresour. Technol. 102 (10), 6326-6330. doi:10.1016/j.biortech.2011.02.045

Hassan, S. S., Ravindran, R., Jaiswal, S., Tiwari, B. K., Williams, G. A., and Jaiswal, A. K. (2020). An evaluation of sonication pretreatment for enhancing saccharification of brewers spent grain. Waste Manag. 105, 240-247. doi:10. 1016/j.wasman.2020.02.012

Huang, C., Lin, W., Lai, C., Li, X., Jin, Y., and Yong, Q. (2019). Coupling the postextraction process to remove residual lignin and alter the recalcitrant structures for improving the enzymatic digestibility of acid pretreated bamboo residues. Bioresour. Technol. 285, 121355. doi:10.1016/j.biortech.2019.121355

Iskalieya, A., Yimmou, B. M., Gogate, P. R., Horvath, M., Harvath, P. G., and Csoka, L. (2012). Cavitation assisted delignification of wheat straw: a review. Ultrason. Sonochem. 19, 984-993. doi:10.1016/j.ultsonch.2012.02.007

Kim, J. S., Lee, Y. Y., and Kim, T. H. (2015). A review on alkaline pretreatment technology for bioconversion of lignocellulosic biomass. Bioresour. Technol. 199, 42-48. doi:10.1016/j.biortech.2015.08.085

Koutsianitis, D., Mitani, C., Giagli, K., Tsalagkas, D., Halasz, K., Kolonics, O., et al. (2015). Properties of ultrasound extracted biocomponent lignocelluloses thin film. Ultrason. Sono Chem. 23, 148-155. doi:10.1016/j.ultsonc.2014.10.014

Lin, W., Xing, S., Jin, Y., Lu, X., Huang, C., and Yong, Q. (2020). Insight into understanding the performance of deep eutectic solvent pretreatment on improving enzymatic digestibility of bamboo residues. Bioresour. Technol. 306, 123163. doi:10.1016/j.biortech.2020.123163

Liu, G., and Bao, J. (2019). Constructing super large scale cellulosic ethanol plant by decentralizing dry acid pretreatment technology into biomass collection depots. Bioresour. Technol. 275, 338-344. doi:10.1016/j.biortech.2018.12.061

Miller, G. M. (1959). Use of dinitrosalicylic acid reagent for determination of reducing sugar. Anal.Chem. 31, 426-428. doi:10.1021/ac60147a030

Ong, V. Z., and Wu, T. Y. (2020). An application for ultrasonication in lignocellulosic biomass valorization into bio-energy and bio-based product. Renew. Sust. Energ. Rev. 132, 109924. doi:10.1016/jrser.2020.109924

Pandey, V. M., and Maiti, D. (2020). "Phragmites species promising perennial grasses for phytoremediation and biofuel production," in Phytoremediation potential of perennial grasses. Editors V. M. Pandey and D. P. Singh (Elsevier), 97-114. doi:10.1016/B978-0-12-817732-7.00005-5

Pandiyan, K., Tiwari, R., Rana, S., Arora, A., Singh, S., and Saxena, A. K. (2014). Comparative efficiency of different pretreatment methods on enzymatic digestibility of Partheniums sp. World J. Microbiol. Biotechnol. 30 (1), 55-64. doi:10.1007/s11274-013-1422-1

Puthiyamadam, A., Adarsh, V. P., Mullepureddy, K. K., Mathew, A., Kumar, J., Yenumala, S. R., et al. (2019). Evaluation of a wet processing strategy for mixed phumdi biomass conversion to ethanol. Bioresour. Technol. 289, 121633. doi:10. 1016/j.biortech.2019.121633

Raiskila, S., Pulkkinen, M., Laakso, T., Fagerstedt, K., Loija, M., and Mahlberg, R. (2007). FTIR spectroscopic prediction of klason and acid soluble lignin variation in Norway spruce cutting clones. Silva. Fenn. 41 (2), 551-571.

Ramadoss, G., and Muthukumar, K. (2016). Mechanistic study of ultrasound pretreatment of sugarcane bagasse using metal salts with hydrogen peroxide for ethanol. Ultrason. Sonochem. 28, 207-217. doi:10.1016/j.ultsonch.2015.07.006

Ravindran, R., and Jaiswal, A. K. (2016). A comprehensive review on pretreatment strategy for lignocellulosic food industrial waste: challenges and opportunities. Bioresour. Technol. 199, 92-102. doi:10.1016/biortech.2015.07.106

Sahoo, D., Ummalyma, S. B., Okram, A. K., Pandey, A., Sankar, M., and Sukumaran, R. K. (2018). Effect of dilute acids pretreatment of wild rice grass (Zizania latifolia) from Loktak Lake for enzymatic hydrolysis. Bioresour. Technol. 253, 252-255. doi:10.1016/j.biortech.2018.01.048

Segal, L., Creely, J. J., Martin, A. E., Jr., and Conrad, C. M. (1959). An empirical method for estimation of the degree of crystallinity of native cellulose using $\mathrm{X}$ ray diffractometer. Text. Res. 29 (10), 786-794. doi:10.1177/004051755902901003

Sindhu, R., Binod, P., Mathew, A. K., Abraham, A., Gnansounou, E., Ummalyma, S. B., et al. (2017). Development of a novel ultrasound assisted alkali pretreatment strategy for the production of bioethanol and xylanases from chilli post harvest residue. Bioresour. Technol. 242, 146-151. doi:10.1016/j.biortech.2017.03.001

Sivagurunathan, P., Kumar, G., Mudhoo, A., Rene, E. R., Saratala, G. D., Kobayashi, T., et al. (2017). Fermentative hydrogen production using lignocelluloses biomass: an overview of pretreatment methods, inhibitor effect and detoxification experiences. Renew. Sus. Energ. Rev. 77, 28-44. doi:10.1016/j.rser.2017.03.091

Sluiter, A., Hanmes, B., Ruiz, R., Scralata, C., Sluiter, J., and Templeron, D. (2011). Determination of carbohydrates and lignin in biomass. NREL/TP-510-42618, Laboratory analytical procedure (LAP), National Renewable Energy Laboratory.

Soares, J., Demeke, M. M., Foulquie-Moreno, M. R., Velde, M. V., Verplaetse, A., Fernandes, A. A. R., et al. (2016). Green coconut mesocarp pretreated by an alkaline process as a raw material for bioethnol production. Bioresour. Technol. 216, 744-753. doi:10.1016/j.biortech.2016.05.105

Sukumaran, R. K., Surender, V. J., Sindhu, R., Binod, P., Janu, K. U., Sajna, K. V., et al. (2010). Lignocellulosic ethanol in India: prospects, challenges and feedstock availability. Bioresour. Technol. 101 (13), 4826-4833. doi:10.1016/j.biortech.2009.11.049

Sun, S., Sun, S., Cao, X., and Sun, R. (2016). The role of pretreatment in improving enzymatic hydrolysis of lignocellulosic materials. Bioresour. Technol. 199, 49-58. doi:10.10.16/j.biortech.2015.08.061

Velmurugan, R., and Muthukumar, K. (2012). Sonoassisted enzymatic saccharification of sugarcane bagasse for ethanol production. Biochem. Eng. 63, 1-9. doi:10.1016/j.bej.2012.01.001

Wang, K., Yang, H. Y., Xu, F., and Sun, R. C. (2011). Structural comparison and enhanced enzymatic hydrolysis of the cellulosic preparation from Populous tomentosa carr. by different cellulose soluble solvent systems. Bioresour. Technol. 102 (6), 4525-4529. doi:10.1016/j.biortech.2010.12.088

Wang, M., Zhou, D., Wang, Y., Wei, S., Yang, W., Kuang, M., et al. (2016). Bioethnaol production from cotton stalk: a comparative study of various pretreatment. Fuel 184, 527-532. doi:10.1016/j.fuel.07.061

Wang, S., Li, F., Zhang, P., Jin, S., Tao, X., Tang, X., et al. (2017). Ultrasound assisted alkaline pretreatment to enhance enzymatic saccharification of grass clipping. Energ. Convers. Manage. 149, 409-415. doi:10.1016/j.enconman.2017.07.042

Wu, H., Dai, X., Zhou, S. L., Gan, Y. Y., Xiong, Z. Y., and Qin, Y. H. (2017). Ultrasound assisted alkaline pretreatment for enhancing the enzymatic hydrolysis of rice straw by using heat energy dissipated from ultrasonication. Bioresour. Technol. 241, 70-74. doi:10.1016/j.biortech.2017.05.090

Zhao, R., Liu, L., Bi, Y., Liang, T., and Wang, X. (2020). Determination of pyrolysis characteristics and thermo-kinetics to assess the bioenergy potential of Phragmites communis. Energy Convers. Manage. 207, 112510. doi:10.1016/j. enconman.2020.112510

Zhong, C., Jia, H., and Wei, P. (2017). Enhanced saccharification of wheat straw with application of ultrasonic assisted quaternary ammonium hydroxide pretreatment. Process. Biochem. 53, 180-187. doi:10.1016/j. procbio.2016.11.004

Zhu, S., Huang, W., Wang, K., Chen, Q., and Wu, Y. (2015). Coproduction of xylose lignosulfonate and ethanol from wheat straw. Bioresour. Technol. 185, 234-239. doi:10.1016/j.biortech.2015.02.115

Conflict of Interest: The authors declare that the research was conducted in the absence of any commercial or financial relationships that could be construed as a potential conflict of interest.

Copyright (C) 2021 Ummalyma, Sahoo, Pudiyamadam, Adarsh, Sukumaran, Bhaskar and Parida. This is an open-access article distributed under the terms of the Creative Commons Attribution License (CC BY). The use, distribution or reproduction in other forums is permitted, provided the original author(s) and the copyright owner(s) are credited and that the original publication in this journal is cited, in accordance with accepted academic practice. No use, distribution or reproduction is permitted which does not comply with these terms. 